UDC 636.32/.38.085.2

Original research paper

doi: 10.5937/AASer1948135S

Acta Agriculturae Serbica, Vol. XXIV, 48(2019); 135-142

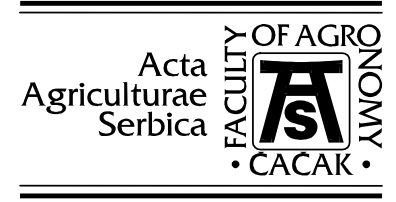

\title{
The influence of the length of fattening and gender of the lambs on the thickness of the subcutaneous fatty tissue
}

\author{
Jasmina Stojiljković ${ }^{1}$, Zoran Stojiljković ${ }^{2}$, Slavica Vesković ${ }^{3}$, Jelena \\ Vanovac $^{4}$, Dragutin Đukić 5 \\ ${ }^{1}$ Department of Food Technology, The Academy of Applied Technical and Preshool \\ Studies, Filip Filipovic 20, 17500 Vranje, Serbia \\ ${ }^{2}$ Interspajs, d.o.o., Sutjeskina 31/1, 17500 Vranje, Serbia \\ ${ }^{3}$ Institute of Meat Hygiene and Technology, Kacanskog 13, 11040 Belgrade, Serbia \\ ${ }^{4}$ State Audit Institution, Makenzijeva 41, 11111 Belgrade, Serbia \\ ${ }^{5}$ Faculty of Agronomy, Cara Dušana 34, 32000 Čačak, Serbia \\ Corresponding author: jasmina_vranje@yahoo.com
}

\begin{abstract}
In this research, three groups of 12 lambs (6 male and 6 female) of the Pirot improved race were examined. The first group of lambs was fattened for 60 days, the second 120 and the third 180 days. Nutrition of the lamb to rejection (40 days) is the mother's milk. After 40 days, it switched to pelleted concentrate (with $18 \%$ protein) and a quality hay, which was ad libidum as the concentrate. At the end of the fattening, the lamb is slaughtered by the usual technique. The objectives of this study were to determine the influence of the length of fattening and gender of the lambs on the thickness of the subcutaneous fatty tissue. Differences in fat in the subcutaneous tissue dorsally, medially and laterally at the intersection between the $12^{\text {th }}$ and $13^{\text {th }}$ vertebrae are significantly different $(\mathrm{P}<0.01)$ both in male and female lambs in all three groups. At the intersection of the lateral side between the $12^{\text {th }}$ and $13^{\text {th }}$ vertebrae there are significant differences $(\mathrm{P}<0.01)$ between the first and second and between the first and third groups in both genders. The subcutaneous fatty tissue in females compared to male lambs is thicker in all measured locations. However, significant differences were found in the thickness of breast tissue $(\mathrm{P}<0.05)$ and dorsal between the $12^{\text {th }}$ and $13^{\text {th }}$ vertebrae $(\mathrm{P}<0.01)$ for lambs of the second group. Female lambs of the third group also have thicker subcutaneous fatty tissue, dorsally and medially between the $12^{\text {th }}$ and $13^{\text {th }}$ vertebrae $(\mathrm{P}<0.05)$.
\end{abstract}


Keywords: subcutaneous fatty tissue, fattening, gender, lamb.

\section{Introduction}

Fat content is important given its impact on the price of the carcass (Díaz et al., 2001). Some of the measurements for this criterion are the thickness of the dorsal fat, the weight of renal pelvic fat, and the visual assessment of the fat content of the carcass (Díaz et al., 2002; Carrasco et al., 2009).

Another variable used as a general indicator of the quality of the carcass is its conformation (Díaz, 2001), which involves a visual assessment and objective measurements such as the width and depth of the thorax, length of legs, width of the rump or the area of the rib eye, among others (Díaz, 2001).

The influence of intramuscular fat (IMF) on tenderness and juiciness varies depending on the study and the species studied (Wood et al., 2008). With sheep, meat with more marbling or IMF is more valued by sensory panels (Fisher et al., 2000; Wood et al., 2008). Similarly, meat with a higher IMF level has a lower shear force value, which nevertheless does not directly relate the IMF level to the degree of tenderness (Sañudo et al., 2000). The fatty acid composition of the meat is very important given its implications for human health (Givens, 2005) in relation to heart disease and cancer (Wood et al., 2003). The fatty acid composition affects characteristics of the meat like juiciness, flavor, shelf life, and firmness of the fat (Wood et al., 2003).

\section{Material and methods}

The experiment included a total of 36 lambs from the purified ennobled sheep divided into 3 groups ( 6 males and 6 females), according to the duration of the fattening period, as follows: I group 60 days fattening; II group 120 days fattening and III group 180 days fattening. The test is performed only in lambs, lambing as unions, at the farm Djumruk on Vlasina Lake, Republic of Serbia, located at an altitude of $1250 \mathrm{~m}$.

The daily meal of sheep breastfeeding from the beginning of the experiment to the $40^{\text {th }}$ day consisted of: seeds $1.8 \mathrm{~kg} /$ throat; silage $1.5 \mathrm{~kg} /$ throat and concentrate $0.5 \mathrm{~kg} /$ throat. In the first 10 days, the mother's milk was present in the diet of the lambs, and from the $11^{\text {th }}$ day until the end of the fattening, all three groups of lambs had at their disposal a pelleted concentrate and a quality seeds at will, whose consumption was monitored and recorded every day. The lambing period of the lambs was completed on the $40^{\text {th }}$ day of their life. In the diet of all three groups of lambs, the pelleted concentrate and the quality seeds were represented until the end of the experiment and that no group was pasture or used any other foods.

After finishing the fattening the lambs were slaughtered in the slaughterhouse Jugokop - Bujanovac, Republic of Serbia, which had an export character, which means that all necessary prerequisites for processing and storage of the meat received were met, according to the strict European standards. Each group of lambs from farm to slaughterhouse was transported by truck. Twelve hours before slaughter, food was 
broken at the lambs, while water was available until loading in a truck. Immediately after the landing of the lambs in the livestock depot, a visual inspection was carried out by the veterinary inspection, which concluded that all the lambs were in good condition, with good health and that they could go to slaughter.

The slaughter of the lambs is carried out according to the technological procedure, according to the following phases: preparing lamb for slaughter; raising to the track; bleeding; removing the skin; evisceration and cooling. After taking the linear measures is done cutting left half on basic parts, and their measurement. Then, the calculated values of the yield of individual tissues (meat, fat, bones) in the main parts of the carcass. After slaughtering the lambs, the primary processing and cooling, the halves are cut into the main parts. The carcasses are cut into the following main parts: round, loin, back, shoulder, neck, breast, ribs, foreshank, belly and lower leg.

The carcasses were taken out of the cold room and the depth of soft tissue was measured with sharpened metal rule. Each joint was dissected and the lean meat, intermuscular and subcutaneous fat were separated from the bones accurately.

Variational statistical analysis was performed by analyzing the variance of twofactorial experiment ( $3 \times 2$ ), according to Sokal and Rohlf, 1995. The differences in the mean values were tested with the Tukey test.

\section{Results and discussion}

The thickness of the subcutaneous fatty tissue for the male lambs ( $\mathrm{mm})$ is given in Table 1, the thickness of the subcutaneous fatty tissue for female lambs ( $\mathrm{mm})$ is given in Table 2, while in Table 3 the thickness of the subcutaneous fatty tissue is determined according to the gender of the lambs $(\mathrm{mm})$.

Table 1. The thickness of the subcutaneous fatty tissue for male lamb (mm)

\begin{tabular}{|c|c|c|c|c|c|c|}
\hline & \multicolumn{6}{|c|}{ Group } \\
\hline & \multicolumn{2}{|c|}{ I } & \multicolumn{2}{|c|}{ II } & \multicolumn{2}{|c|}{ III } \\
\hline & $\bar{X}$ & $\mathrm{SD}$ & $\bar{X}$ & SD & $\bar{X}$ & SD \\
\hline On breast & $6.83^{a}$ & 1.47 & $7.33^{\mathrm{a}}$ & 0.82 & $\underset{\mathrm{b}}{10.50}$ & 2.07 \\
\hline At the root of the tail & $5.00^{\mathrm{a}}$ & 1.79 & $6.33^{\mathrm{a}}$ & 0.82 & $9.17^{\mathrm{b}}$ & 2.23 \\
\hline $\begin{array}{l}\text { Dorsally (between the } 12^{\text {th }} \\
\text { and } 13^{\text {th }} \text { vertebrae ) }\end{array}$ & $3.83^{\mathrm{a}}$ & 1.33 & $5.83^{b}$ & 0.98 & $7.83^{c}$ & 1.17 \\
\hline $\begin{array}{l}\text { Medially (between the } 12^{\text {th }} \\
\text { and } 13^{\text {th }} \text { vertebrae) }\end{array}$ & $2.83^{\mathrm{a}}$ & 0.98 & $5.50^{b}$ & 0.55 & $6.50^{\mathrm{c}}$ & 1.05 \\
\hline $\begin{array}{l}\text { Laterally (between the } 12^{\text {th }} \\
\text { and } 13^{\text {th }} \text { vertebrae) }\end{array}$ & $4.50^{\mathrm{a}}$ & 1.64 & $6.67^{b}$ & 1.03 & $9.00^{\mathrm{c}}$ & 1.27 \\
\hline $\begin{array}{c}\text { On the side of between the } \\
12^{\text {th }} \text { and } 13^{\text {th }} \text { vertebrae }\end{array}$ & $5.20^{\mathrm{a}}$ & 1.21 & $7.33^{b}$ & 0.82 & $\underset{b}{10.50}$ & 1.38 \\
\hline
\end{tabular}


Table 2. The thickness of the subcutaneous fatty tissue for female lamb (mm)

\begin{tabular}{|c|c|c|c|c|c|c|}
\hline & \multicolumn{6}{|c|}{ Group } \\
\hline & \multicolumn{2}{|c|}{ I } & \multicolumn{2}{|c|}{ II } & \multicolumn{2}{|c|}{ III } \\
\hline & $\bar{X}$ & SD & $\bar{X}$ & SD & $\bar{X}$ & SD \\
\hline On breast & $7.50^{\mathrm{a}}$ & 1.64 & $9.17^{\mathrm{a}}$ & 1.72 & $11.83^{\mathrm{b}}$ & 1.33 \\
\hline At the root of the tail & $6.17^{\mathrm{a}}$ & 1.47 & $7.33^{\mathrm{a}}$ & 1.21 & $9.83^{\mathrm{b}}$ & 1.17 \\
\hline $\begin{array}{l}\text { Dorsally (between the } 12^{\text {th }} \\
\text { and } 13^{\text {th }} \text { vertebrae ) }\end{array}$ & $4.17^{\mathrm{a}}$ & 1.17 & $7.67^{\mathrm{b}}$ & 1.03 & $9.67^{c}$ & 1.21 \\
\hline $\begin{array}{l}\text { Medially (between the } 12^{\text {th }} \\
\text { and } 13^{\text {th }} \text { vertebrae) }\end{array}$ & $2.83^{\mathrm{a}}$ & 0.75 & $6.50^{b}$ & 0.55 & $8.33^{c}$ & 0.82 \\
\hline $\begin{array}{l}\text { Laterally (between the } 12^{\text {th }} \\
\text { and } 13^{\text {th }} \text { vertebrae) }\end{array}$ & $5.00^{\mathrm{a}}$ & 1.67 & $7.50^{b}$ & 1.05 & $10.33^{\mathrm{c}}$ & 0.82 \\
\hline $\begin{array}{l}\text { On the side of between the } \\
12^{\text {th }} \text { and } 13^{\text {th }} \text { vertebrae }\end{array}$ & $6.17^{\mathrm{a}}$ & 0.75 & $8.67^{b}$ & 1.51 & $12.17^{\mathrm{b}}$ & 0.75 \\
\hline
\end{tabular}

On the breast and tail, there is a significant difference $(\mathrm{P}<0.01)$ between the first and third, as well as between the second and third groups both in male and female lambs. Differences in fat in the subcutaneous tissue dorsally, medially and laterally at the intersection between the $12^{\text {th }}$ and $13^{\text {th }}$ vertebrae are significantly different $(\mathrm{P}<0.01)$ both in male and female lambs in all three groups. At the intersection of the lateral side between the $12^{\text {th }}$ and $13^{\text {th }}$ vertebrae there are significant differences $(\mathrm{P}<0.01)$ between the first and second and between the first and third groups in both genders.

Various authors (Díaz et al., 2002; Cañeque et al., 2003; Karim et al., 2007; Ekiz et al., 2012) reported higher fatness level in lambs fed concentrate in sheepfold than lambs fed on pasture and concomitant dressing percentage increase. Peña et al.. (2005) also reported an increase in fatness level of carcass with increasing slaughter weight of lambs.

Table 3 shows that fatty tissue in females compared to male lambs is thicker in all measured locations. However, significant differences were found in the thickness of breast tissue $(\mathrm{P}<0.05)$ and dorsal between the $12^{\text {th }}$ and $13^{\text {th }}$ vertebrae $(\mathrm{P}<0.01)$ for lambs of the second group. Female lambs of the third group also have thicker subcutaneous fatty tissue, dorsally and medially between the $12^{\text {th }}$ and $13^{\text {th }}$ vertebrae $(\mathrm{P}<0.05)$. 
Table 3. The thickness of the subcutaneous fatty tissue according to gender of the lambs $(\mathrm{mm})$

\begin{tabular}{|c|c|c|c|c|}
\hline Measuring places & Group & Male & Female & Differences \\
\hline \multirow{3}{*}{ On breast } & I & 6.83 & 7.50 & $0.67^{\mathrm{ns}}$ \\
\hline & II & 7.33 & 9.17 & $1.84 *$ \\
\hline & III & 10.80 & 11.83 & $1.33^{\mathrm{ns}}$ \\
\hline \multirow{3}{*}{ At the root of the tail } & $\mathrm{I}$ & 5.00 & 6.17 & $1.17^{\mathrm{ns}}$ \\
\hline & II & 6.33 & 7.33 & $1.00^{\mathrm{ns}}$ \\
\hline & III & 9.17 & 9.83 & $0.66^{\mathrm{ns}}$ \\
\hline \multirow{3}{*}{ Dorsally (between the $12^{\text {th }}$ and $13^{\text {th }}$ vertebrae ) } & I & 3.83 & 4.17 & $0.34^{\mathrm{ns}}$ \\
\hline & II & 5.83 & 7.67 & $1.84^{* * *}$ \\
\hline & III & 7.83 & 9.67 & $1.84^{*}$ \\
\hline \multirow{3}{*}{ Medially ( between the $12^{\text {th }}$ and $13^{\text {th }}$ vertebrae) } & I & 2.83 & 2.83 & $0.00^{\mathrm{ns}}$ \\
\hline & II & 5.50 & 6.50 & $1.00^{\mathrm{ns}}$ \\
\hline & III & 6.50 & 8.33 & 1.83 * \\
\hline \multirow{3}{*}{ Laterally ( between the $12^{\text {th }}$ and $13^{\text {th }}$ vertebrae) } & $\mathrm{I}$ & 4.50 & 5.00 & $0.50^{\mathrm{ns}}$ \\
\hline & II & 6.67 & 7.50 & $0.83^{\mathrm{ns}}$ \\
\hline & III & 9.00 & 10.33 & $1.33^{\mathrm{ns}}$ \\
\hline \multirow{2}{*}{$\begin{array}{l}\text { On the side of between the } 12^{\text {th }} \text { and } 13^{\text {th }} \\
\text { vertebrae }\end{array}$} & II & 7.33 & 8.67 & $1.34^{\mathrm{ns}}$ \\
\hline & III & 10.50 & 12.17 & $1.67^{\mathrm{ns}}$ \\
\hline
\end{tabular}

* - The gender differences are significant at the level $\mathrm{P}<0.05 ; * *$ - The gender differences are significant at the level $\mathrm{P}<0.01 ; \mathrm{ns}-$ The gender differences are not significant

The percentage of fat trimmings in carcass and the tissue composition of sample cut were influenced by a significant interaction between age-class and sex $(\mathrm{P}<0.05)$ : in males the age-class never affected the tissue composition of sample cut, as in females the muscle and fat percentages increased with age while the bone percentage decreased. The fat content of loin meat increased with age in females $(\mathrm{P}<0.05)$ and decreased in males $(\mathrm{P}<0.05)$. The poly-unsaturated fatty acids $(\mathrm{FA})$ content of loin meat was higher in males than in females $(\mathrm{P}<0.001)$, with saturated FA and mono-unsaturated FA revealing significant interactions between age-class and sex $(\mathrm{P}<0.05)$, Sabbioni et al., (2016). 


\section{Conclusion}

Resuls showed that on the breast and tail, there was a significant difference $(\mathrm{P}<0.01)$ between the first and third, as well as between the second and third groups both in male and female lambs. Differences in fat in the subcutaneous fatty tissue dorsally, medially and laterally at the intersection between the $12^{\text {th }}$ and $13^{\text {th }}$ vertebrae are significantly different $(\mathrm{P}<0.01)$ both in male and female lambs in all three groups. At the intersection of the lateral side between the $12^{\text {th }}$ and $13^{\text {th }}$ vertebrae there are significant differences $(\mathrm{P}<0.01)$ between the first and second and between the first and third groups in both genders. The subcutaneous fatty tissue in females compared to male lambs is thicker in all measured locations. However, significant differences were found in the thickness of breast tissue $(\mathrm{P}<0.05)$ and dorsal between the $12^{\text {th }}$ and $13^{\text {th }}$ vertebrae $(\mathrm{P}<0.01)$ for lambs of the second group. Female lambs of the third group also have have thicker subcutaneous fatty tissue, dorsally and medially between the $12^{\text {th }}$ and $13^{\text {th }}$ vertebrae $(\mathrm{P}<0.05)$.

\section{Acknowledgments}

This work is the result of a project funded by the Ministry of Education, Science and Technological Development of the Republic of Serbia III 46009.

\section{References}

Cañeque V., Velasco S., Diaz M.T., Huidobro F.R., Perez C., Lauzurica. S. (2003): Use of whole barley with a protein supplement to fatten lambs under different management systems and its effect on meat and carcass quality. Animal Research, 52: 271-285.

Carrasco S., Ripoll G., Sanz A., Álvarez-Rodríguez J., Panea B., Revilla R., et al. (2009): Effect of feeding system on growth and carcass characteristics of Churra Tensina light lambs. Livestock Science, 121: 56-63.

Díaz M. (2001): Características de la canal y de la carne de corderos lechales manchegos. Correlaciones y ecuaciones de predicción. Tesis PhD, Universidad Complutense de Madrid, Facultad Veterinaria, Madrid, España.

Díaz M., Velasco S., Cañeque V., Lauzurica S., Ruiz de Huidobro F., Pérez, C., et al. (2002): Use of concentrate or pasture for fattening lambs and its effect on carcass and meat quality. Small Ruminant Research, 43:257-268.

Ekiz B., Yilmaz A., Ozcan M., Kocak O. (2012): Effect of production system on carcass measurement and meat quality of Kivircik lambs. Meat Science, 90: 465-471.

Fisher A., Enser M., Richardson R., Wood J., Nute G., Kurt E., et al. (2000): Fatty acid composition and eating quality of lamb types derived from four diverse breed production systems. Meat Science, 55: 141-147.

Givens D. (2005): The role of animal nutrition in improving the nutritive value of animal-derived foods in relation to chronic disease. Proceedings of the Nutrition Society, 64: 395-402.

Karim S. A., Porwal K., Kumar S., Singh V. K. (2007): Carcass traits of Kheri lambs maintained on different system of feeding management. Meat Science, 76: 395-401. 
Peña F., Cano T., Domenech V., Alcalde M., Martos J., García-Martinez A., Herrera M., Rodero E. (2005): Influence of sex. slaughter weight and carcass weight on "non-carcass" and carcass quality in segureñ lambs. Small Ruminant Research, 60: 247-254.

Sabbioni A., Beretti V., Zambini E.M., Superchi P. (2016): Carcass and meat parameters in Cornigliese sheep breed as affected by sex and age-class. Italian Journal of Animal Science, 15 (1): 2-9.

Sañudo C., Alfonso M., Sánchez A., Delfa R., Teixeira A. (2000): Carcass and meat quality in light lambs from different fat classes in the EU carcass classification system. Meat Science, 56: 89-94.

Sokal R.R., Rohlf J.F. (1995): Biometry. Freeman and Company. New York.

Wood J., Richardson R., Nute G., Fisher A., Campo M., Kasapidou E. et al. (2003): Effects of fatty acids on meat quality: A review. Meat Science, 66: 21-32.

Wood J., Enser M., Fisher A., Nute G., Sheard P., Richardson R., et al. (2008): Fat deposition, fatty acid composition and meat quality: A review. Meat Science, 78:343-353. 


\title{
UTICAJ DUŽINE TOVA I POLA JAGNJADI NA DEBLJINU POTKOŽNOG MASNOG TKIVA
}

\author{
Jasmina Stojiljković ${ }^{1}$, Zoran Stojiljković ${ }^{2}$, Slavica Vesković ${ }^{\mathbf{3}}$, Jelena \\ Vanovac $^{4}$, Dragutin Đukić ${ }^{5}$ \\ ${ }^{1}$ Akademija tehničko-vaspitačkih strukovnih studija, Filipa Filipovića 20, 17500 Vranje, \\ Srbija \\ ${ }^{2}$ Interspajs, d.o.o., Sutjeskina 31/1, 17500 Vranje, Srbija \\ ${ }^{3}$ Institut za higijenu i tehnologiju mesa, Kaćanskog 13, 11040 Beograd, Srbija \\ ${ }^{4}$ Državna revizorska institucija, Makenzijeva 41, 11111 Beograd, Srbija \\ ${ }^{5}$ Agronomski fakultet, Cara Dušana 34, 32000 Čačak, Srbija
}

\begin{abstract}
Rezime
U ovom istraživanju ispitivane su tri grupe od 12 jagnjadi (6 muškog i 6 ženskog pola) pirotske oplemenjene rase ovaca. Prva grupa jagnjadi je provela u tovu 60, druga 120 i treća 180 dana. Ishrana jagnjadi tokom 40 dana je bilo majčino mleko. Posle 40 dana, u ishrani jagnjadi je korišćen peletirani koncentrat (sa 18\% proteina) i kvalitetno seno, ad libidum. Klanje jagnjadi je obavljeno uobičajenom tehnikom. Ciljevi ove studije bili su utvrđivanje uticaja dužine tova i pola jagnjadi na debljinu potkožnog masnog tkiva. Razlike u debljini potkožnog masnog tkiva dorzalno, medijalno i lateralno na preseku između 12. i 13. pršljena su značajno različite $(\mathrm{P}<0.01)$ i kod muških i kod jagnjadi u sve tri grupe. Na preseku sa lateralne strane između 12. i 13. pršljena postoje razlike na nivou $\mathrm{P}<0.01$ između prve $\mathrm{i}$ druge, te između prve i treće grupe, oba pola. Potkožno masno tkivo kod ženske u odnosu na mušku jagnjad je deblje na svim merenim mestima. Međutim, utvrđene su značajne razlike u debljini potkožnog masnog tkiva grudi $(\mathrm{P}<0.05)$ i dorzalnom delu između 12. i 13. pršljena $(\mathrm{P}<0.01)$ kod jagnjadi druge grupe. Ženska jagnjad treće grupe takođe imaju deblje potkožno masno tkivo, dorzalno i medijalno između 12. i 13. pršljena $(\mathrm{P}<0.05)$.
\end{abstract}

Ključne reči: potkožno masno tkivo, tov, pol, jagnjad. 